\title{
A Theological Reflection on the Concept of Sin in Christianity
}

\section{Peter Addai-Mensah'}

${ }^{1}$ Department of Religious Studies, Kwame Nkrumah University of Science and Technology ,Ghana.

\begin{abstract}
The concept of sin is a phenomenon that no one can gloss over. It is a reality. It permeates the whole of human existence. All the major religions in the world grapple with it as far as relationship with God is concerned. This article discusses the concept of sin. It looks at it from the point of view of Christianity. The article examines how various scholars have defined sin from their own perspectives. It looks at the types of sin, how sin originated and made its presence in the world and the consequences of sin. Finally, the article accounts for the theological implications of sin. It points out that among other things: sin destroys the relationship between God and the human person; separation from God because of sin leads to death and destruction; the concept of sin necessitated the coming of Jesus Christ to bring salvation and liberation to the world. The article does not use a case study. The author uses the literary approach and therefore uses library sources.
\end{abstract}

Keywords: Sin, Christianity, Theological Implication.

\author{
Correspondence: \\ Peter Addai-Mensah Email: \\ addamens@yahoo.com \\ Manuscript \\ Received 13th July, 2020, \\ Accepted 24th August 2020, \\ Published online 26th August \\ 2020.
}

\section{INTRODUCTION}

Scripture clearly indicates the fact that the human being was created in the image and likeness of God. It is always very important to know as human beings the things which keep one close to God and the ones which keep God far away from mankind. Certain acts of conduct make one feel good while others make one feel downhearted. In other words, there are certain things which make the human being feel good in his/her spirit and there are others which make him/ her feel unhappy.

God's creation according to the writer of the book of Genesis "is good" - (cf. Gen. 1:31). That gives a clear picture of how God saw things when God created everything including humankind. If the creation of God is good then human beings using God's creation should enjoy it by feeling the goodness in it. However, this is not the case. This has been a condition that is brought about by sin. According to Emmanuel Asante, "the human is entangled with the forces of negation, something in his own condition against which the human needs to be guarded, and from which he needs to be preserved or freed, and of which he must be made aware."' The inability of the human being to enjoy what the Creator originally planned is as a result of certain negatives that are working against his/her effort to enjoy opportunities the Creator has created. Paul explains it in the scripture when he cried about his inability to live up to expectation:

I do not understand what I do. For what I want to do I do not do, but what I hate I do. And if I do what I do not want to do, I agree that the law is good. As it is, it is no longer I myself who do it, but it is sin living in me. I know that nothing good lives in me, that is, in my sinful nature. For I have the desire to do what is good, but I cannot carry it out. For what I do is not the good I want to do; no, the evil I do not want to do - this I keep on doing. Now if I do what I do not want to do, it is no longer I who do it, but it is sin living in me that does it. ${ }^{3}$

It is clear from the above passage that Paul as a human being had a desire to do something good as originally was inherent in humankind at creation. However, there seems to be a certain inability (force) to do such good as he shows his frustrations. Paul attributed this inability to do the good he had wanted to do to sin. Asante agrees with Paul when he

\footnotetext{
Emmanuel Asante, Soteriology: A Discourse on Salvation, (Accra: Pinpoint Media co. Ltd, 2014), 2.

Romans 7:15-20 NIV.
} 
states that there is a certain force of negation. This force of negation is what entangles humans and for that matter urged Paul to go against what he had wished for.

\section{Definition of Sin}

Sin is any action or inaction that goes against what is expected from humankind by the Creator and mars the relationship with God. The New Dictionary of Theology describes sin as a deliberate violation of a precept of God by going beyond what the limit defined by the precept. ${ }^{4}$ This means sin is the situation when one does something against the precept or when one refuses to do something required by the precept of God. Both action and inaction become sin.

Citing two definitions from Augustine and Thomas Aquinas, sin is defined as "anything done, said, or desired against the eternal law" and "turning away from God and turning towards the creature" respectively. ${ }^{5}$ Anything done or even anticipated in the heart which does not fall in line with the word of God is sin and it amounts to the turning away from God to God's creature instead. The refusal to live up to the requirement of a divine command amounts to the obedience on the part of the creature of God.

John R. Sachs notes, "Sin is seen as a transgression of a divine command, rebellion against God and God's authority." Adam for instance was given a command and not obeying it meant breaking that divine command. Sachs further uses Old Testament words like Hatta, Awon and Pesa and New Testament words like Paraptoma, Parabsis and Hamartia which show the fact that sin which leads to turning away with a hardened heart and stiff-neckedness is committed by humankind against the expectations of God. ${ }^{7}$

\section{Classification of Sin}

In Catholic theology sin is classified into two types; original and actual sin and a further classification into mortal and venial sin according to its severity. Original sin is seen as one inherited as human being from Adam and Eve and it affects every person while actual sin is one committed personally by every human being.

Classifying sin according to its severity sees sin as mortal and venial. Mortal sin is one that leads to death according to 1 John 5:16. It affects the soul and leads to its death. While venial sin does not affect the soul and does not lead to its death. According to Sachs, Catholic tradition teaches that some sins are relatively minor (venial) and others so serious that they are called deadly (mortal). ${ }^{8}$ Jesus' answer to Pilate that "he who handed me over to you has done a greater sin" as found in John 19:11 implies that some sins can be greater than others. Komonchak, Collins and Lane might perhaps have this at the back of their minds when they indicate that "although the scriptures do not formally distinguish between mortal and venial sins, both Testaments bear witness to the distinction." This can clearly be seen in how some sins are punishable by extinction from among God's people - (cf. Leviticus 7:25) and other sins were merely pardoned after a required sacrifice - (cf. Leviticus 4:5).

\section{Origin of Sin}

Looking for the origin of sin takes one back to the Old Testament account in Genesis. This can be seen in the first three chapters which tell of the disobedience to God's instruction by Adam and Eve in the Garden of Eden. In the opinion of Asante the origin of sin is traceable to "the Adamic myth generally presented in the primeval history of Genesis 1-11, specifically Genesis 1-3." ${ }^{10}$ Analyzing Asante's position, the origin of sin cannot be taken out of the creation story since it is that story that tells of what Adam and Eve did in disobedience to God. Although Herbert Lockyer sees sin as old as human life he took it further back before creation. According to him, sin originated in the mind of Satan before all things were made. ${ }^{11}$ Lockyer's position agrees with Asante's that sin is primeval but Satan considering sin in his thought makes sin older than Adam and Eve. This is what Lockyer stresses when he writes that Satan was the first sinner through pride and his desire to be equal with God (Isaiah 14:12-14). ${ }^{12}$ This author agrees with Lockyer that sin originated with Satan and before humankind was created.

Charles R. Swindoll also stressed that with respect to sin the trouble of human being began with Adam and his wife sinning against the instruction of God. ${ }^{13}$ Sin therefore originated with Satan and not the first human.

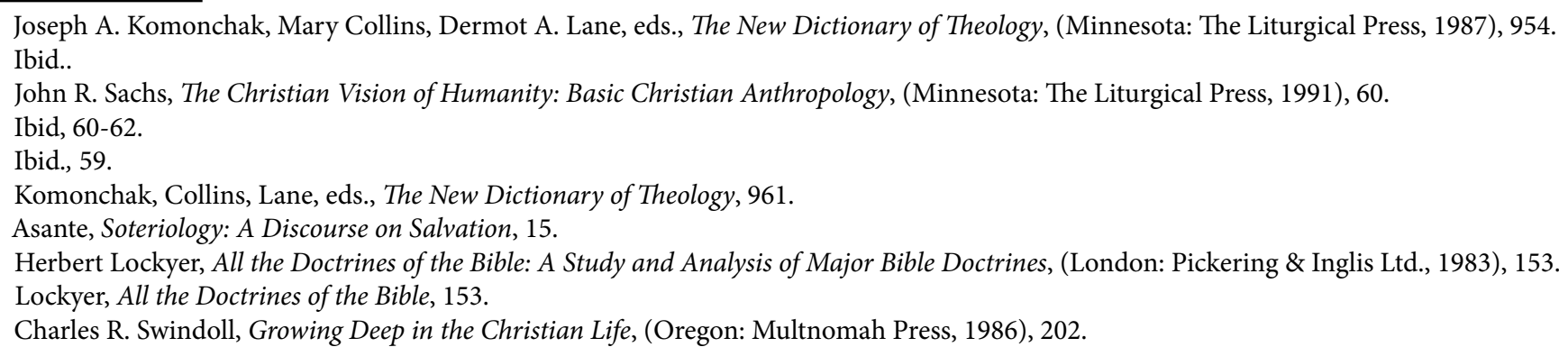




\section{Effects of Sin}

As indicated earlier on, sin makes humankind turn against God but towards God's creation. Lockyer writes that "since sin's entrance into the world it has become universal. All have sinned (cf. Romans 5:12)."14 Through the original sin, everyone becomes a sinner through the first parents. Sin becoming universal is the means by which all are affected. Adam is representative of all humanity. His fall then is the fall of all humanity ${ }^{15}$ For Asante, humankind's representation in Adam makes all humanity to fall as Adam did and as Romans 5:15 expounds.

Humanity is devastated, decayed and deteriorated by the incidence of sin. Lockyers describes the situation one goes through by the emergence of sin and states that all are ruined by the fall. ${ }^{16}$ Depreciation has thus set in.

Asante describes the effect of sin on humanity and says: "acting in obedience constitutes actual communion with God. Failing to act in obedient ways point to a deformity in one's actual relationship with creation and to a deformity inwardly in the way the soul and the body are interrelated." ${ }^{17}$ Because of sin, humankind does not enjoy the original communion one had with God and this has caused a distortion in one's relationship with creation and a defect in both his/her body and soul. "Failure to commune with God in obedience is not just one more mistake; it brings with it a radical deformity of oneself in respect of a harmonious relationship with God, nature, and oneself that is referred to alienation from God."18

Swindoll writing about the effect of sin says that a harmonious relationship between human beings and God makes human beings enjoy God's sweet presence leading to the absence of rebellion, selfishness, defensiveness and embarrassment that goes with them. ${ }^{19}$ The author agreeing with Swindoll states that whenever there is sin, its resultant effects lead to embarrassment which is a defect in the life of humankind. Thus, Adam and Eve who initially were not ashamed of their nakedness became embarrassed at the instance of the visit of God and therefore had to go and hide themselves. One cannot agree more with Swindoll when he shows that the very awful moment the first couple yielded to the temptation, depravity entered and contaminated the bloodstream of human beings. ${ }^{20}$ Sin's effect on Adam and Eve and for that matter humans is very injurious. This is what Swindoll calls an internal disease which cannot be detected from outside... but deep down inside it eats the human person away and pollutes his thought and words, and his relationships and eventually his actions. ${ }^{21}$ It is as a matter of fact that sin has made the human person come short of the glory of God as Paul laments in Romans 3:23.

\section{Theological Implications}

According to the bible after God had created humankind from the clay of the earth, God breathed into his nostrils. It was only then that man became a living being - (cf. Gen. 2:7ff). It means that man is by nature intrinsically linked with God. It implies that man is completely and totally dependent on God. This is captured beautifully by Augustine when he said, "you have made us for yourself and our hearts are restless until they rest in you." 22 The theological implication is that humankind can never be autonomous and live independently of God. Any attempt for humanity to do anything without deference first to God will be an exercise in futility.

In addition to that God is the author of life. Since human life emanates from God, it means that all movements of humankind must be towards God. To turn away from God - the author of life -means that one is heading towards death and destruction. This is affirmed by Moses when he addressed the people of Israel at a certain point in time:

See, I have set before you today life and prosperity, death and adversity. If you obey the commandments of the Lord your God that I am commanding you today, by loving the Lord your God, walking in his way and observing his commandments, decrees and ordinances, then you shall live and become numerous, and the Lord your God will bless you in the land that you are entering to possess. But if your heart turns away and you do not hear but are led astray to bow down to other gods and serve them, I declare to you today that you shall perish, and you shall not live long in the land that you are crossing the Jordan to enter and possess. I call heaven and earth to witness against you today that I have set before you life and death, blessings and curses. Choose life so that you and your descendants may live - Deut. 30:15-19.

The concept of sin in Christianity brings out the fact that humanity is handicapped through the original sin by Adam and Eve and also by the actual sin he/she commits. Sin damaged humankind's relationship with God and that led to the depravity of humans. The fallen state therefore suggests a need for a savior to save humanity from the current state and then repair the marred relationship with their creator. Lockyer expresses categorically that "the biblical concept of sin

\footnotetext{
${ }_{4}$ Lockyer, All the Doctrines of the Bible, 153.

Asante, Soteriology: A Discourse on Salvation, 16.

Lockyer, All the Doctrines of the Bible, 153.

Asante, Soteriology: A Discourse on Salvation, 9.

Ibid.

Swindoll, Growing Deep in the Christian Life, 202.

Ibid.

Ibid.

Augustine, Confessions. Henry Chadwick, trans. (Oxford. University Press, 199)1, 1.
} 
is a kind of rule by which we measure the necessity for a savior."23 Thus, the Christian concept of sin reveals what God hates and its attendant divine provision. Humanity's need for a savior is met in the person of Jesus Christ - (cf. Matthew 1:21; John 4:42) as nobody is in the position of saving himself/herself. In Jesus' encounter with the woman at the well, the people who followed her to Jesus declared (after she had moved to town to call on others to come and see Jesus), 'we now believe not because of what the woman told us but because of what we have seen and heard and that this man is the savior of the world. ${ }^{24}$ The concept of sin hence, gives humanity the opportunity to access the salvation provided by God which is in Christ Jesus.

Salvation by Jesus Christ must not only be seen in religious terms. It encompasses all the facets of human life. The mission of Jesus on earth was purposely that human beings may have life and have it abundantly - (cf. Jn. 10:10b). Analyzing the mission of Jesus on earth, Jürgen Moltmann posits "mission embraces all activities that liberate the human person from his/her slavery in the presence of the coming God, slavery which extends from economic necessity to Godforsakenness." ${ }^{25}$ It means that salvation and liberation go hand-in-hand.

In the opinion of Leonardo Boff and Clodovis Boff "salvation and liberation are distinct but they are united, without confusion and without separation." ${ }^{26}$ They believe that "salvation is the great reality within which liberation is situated." ${ }^{27}$ The same opinion is shared by Gustavo Gutierrez who believes that "all efforts to build a just society is liberating. It is salvific work although it is not all of salvation." ${ }^{28}$

In sum, the salvation brought by Jesus Christ includes liberation from all shackles of human life - (cf. Lk. 4:18-19).

\section{CONCLUSION}

Sin which is described as a disobedience to a divine command and being part of the creation story is seen as originating with the devil when he conceived in his mind to become like God (Isaiah 14:12-14). Adam and Eve yielding to sin made it original for all to be inherently sinners. The severity of sin according to scriptures makes it mortal (sin that leads to death) or venial (the sin that does not lead to death) with its effect deforming one in one's relationship with God. The Christian teachings about sin make one aware of the provision made by God in Jesus Christ. This is grace - an unmerited favor from God. It is for this reason that Paul in his letter to the Christian community in Rome said, "where sin abounds grace abounds all the more" - (cf. Rom. 5:20b). In the opinion of Paul grace is simply the Christ-event. In other words, it means Jesus Christ coming to live among human beings and dying on the cross for them.

\section{BIBLIOGRAPHY}

Asante, Emmanuel. Soteriology: A Discourse on Salvation. Accra: Pinpoint Media Co. Ltd, 2014.

Augustine. Confession. Henry Chadwick, Translator. Oxford: University Press, 1991.

Boff, Leonardo and Clodovis Boff. Salvation and Liberation. Maryknoll, NY: Orbis, 1986.

Gustavo, Gutierrez. A Theology of Liberation. Maryknoll, NY: Orbis Books, 1971,

Komonchak, A. Mary Collins and Dermot A. Lane. Editors. The New Dictionary of Theology. Minnesota: The Liturgical Press, 1987.

Lockyer, Herbert. All the Doctrines of the Bible: A Study and Analysis of Major Bible Doctrines. London: Pickering \& Inglis Ltd., 1983.

Moltmann, Jurgen. The Church in the Power of the Spirit. New York: Harper and Row, 1997.

Sachs, John R. The Christian Vision of Humanity: Basic Christian Anthropology. Minnesota: The Liturgical Press, 1991.

Swindoll, Charles R. Growing Deep in the Christian Life. Oregon: Multnomah Press, 1986.

\section{ABOUT AUTHOR}

Peter Addai-Mensah(STD) is a Catholic priest of the Archdiocese of Kumasi and a Senior Lecturer at the Department of Religious Studies, Kwame Nkrumah University of Science and Technology, (KNUST), Kumasi-Ghana.. He has authored six books and co-authored six other books. He has eighteen articles to his credit. His areas of research are Theology and Spirituality.

\footnotetext{
23 Lockyer, All the Doctrines of the Bible, 157.

John 4:42

5 Jurgen Moltmann, The Church in the Power of the Spirit, (New York: Harper and Row, 1997), 10.

${ }^{26}$ Leonardo Boff and Clodovis Boff, Salvation and Liberation, (Maryknoll, NY: Orbis Books, 1986), 59.

27 Ibid.

8 Gustavo Gutierrez, A Theology of Liberation, (Maryknoll, NY: Orbis Books, 1971), 11.
} 